\title{
КОНСУЛЬТАЦИИ
}

\section{CHALLENGES FOR FIRST-YEAR UNDERGRADUATES WITH A NON-EMI BACKGROUND IN AN EMI CLASSROOM: A CASE STUDY}

\author{
K. A. Siddiqui \\ Sukkur IBA University, \\ Sukkur, Pakistan. \\ E-mail: Kamran.akhtar@iba-suk.edu.pk
}

\begin{abstract}
Introduction. English has been the official language as well as medium of instruction (MOI) in higher education of Pakistan for over 70 years despite decolonisation in Asia in 1950s. However, the majority of undergraduates come from non-EMI (English as a medium of instruction) background because MOI in private or public primary and secondary schools is either regional or local language. Therefore, first year undergraduates face challenges in EMI classrooms at university.

Aim. This study aimed to investigate the challenges first year undergraduates with nonEMI background face in an EMI classroom in a public sector university in Sukkur, Pakistan.

Methodology and research methods. Using the case study approach, six purposively selected participants were interviewed using semi-structured interviews as the data collection tool.

Results and scientific novelty. The findings reveal that the learners face issues such as ineffective presentation, incoherent answers in writing, difficult grammatical structures, lack of vocabulary and partial comprehension of content. One of the key findings of the study is the psychological pressure students experience in an EMI classroom. The research is novel in the sense it brings to light language-related issues faced by students such as lack of vocabulary, improper organisation of ideas, and the role of varied language level of books and teachers. Since these challenges have not been explored at undergraduate level, and that too for students from non-EMI background, the study bears great significance for all stakeholders to develop effective strategies for future.

Practical significance. The study will have implications for both policymakers and practitioners in higher education of Pakistan.

Keywords: English as medium of instruction, higher education, English language, challenges.

For citation: Siddiqui K. A. Challenges for first-year undergraduates with a non-EMI background in an EMI classroom: A case study. The Education and Science Journal. 2021; 23 (8): 189-201. DOI:10.17853/1994-5639-2021-8-189-201
\end{abstract}




\title{
ТРУДНОСТИ СТУДЕНТОВ-ПЕРВОКУРСНИКОВ (ДЛЯ КОТОРЫХ АНГЛИЙСКИЙ ЯЗЫК НЕ ЯВЛЯЕТСЯ РОДНЫМ) ПРИ ИСПОЛЬЗОВАНИИ АНГЛИЙСКОГО КАК ЯЗЫКА ОБУЧЕНИЯ: ПРИМЕР ИЗ ПРАКТИКИ
}

\author{
К. А. Сиддики \\ Университет Суккур IBA, \\ Суккур, Пакистан. \\ E-mail: Kamran.akhtar@iba-suk.edu.pk
}

\begin{abstract}
Аннотация. Введение. Английский был официальным языком, а также средством обучения в высшем образовании Пакистана на протяжении более чем 70 мет, несмотря на деколонизацию в Азии в 1950-х годах. Тем не менее большинство студентов не имеют опыта использования английского языка как языка обучения, потому что как в частных, так и в государственных начальных и средних школах используется региональный или местный язык. Таким образом, в университете первокурсники сталкиваются с проблемами при обучении на английском языке.

Цель. Данное исследование направлено на изучение проблем, с которыми сталкиваются студенты первого курса в государственном университете в Суккуре (Пакистан), ранее не обучавшиеся на английском языке.

Методология и методы исследования. В ходе тематического исследования шесть специально отобранных участников были опрошены с использованием полуструктурированных интервью в качестве инструмента сбора данных.

Результаты и научная новизна. Результаты показывают, что учащиеся сталкиваются с такими проблемами, как неэффективное изцожение, непоследовательные письменные ответы, сложные грамматические структуры, недостаток словарного запаса и частичное понимание содержания. Одним из ключевых результатов исследования является психологическое давмение, которое студенты испытывают при обучении на английском языке. Исследование является новым в том смысле, что оно позволяет выявить связанные с языком проблемы, с которыми сталкиваются студенты: бедный словарный запас, неправимьная организация идей, разная сложность учебных пособий и разный языковой уровень преподавателей.

Практическое значение. Исследование имеет значение как дмя представителей помитических структур, так и для практиков в сфере высшего образования Пакистана, а также для всех заинтересованных сторон в разработке эффективных стратегий в будущем.
\end{abstract}

Ключевые слова: английский язык, средство обучения, ЕМІ, высшее образование, английский язык, трудности.

для иитирования: Сидикки К. А. Трудности студентов-первокурсников (для которых английский язык не является родным) при использовании английского как языка обучения: пример из практики // Образование и наука. 2021. T. 23, № 8. С. 189 -201. DOI: 17853/1994-5639-2021-8-189-201

Образование и наука. Том 23, № 8. 2021 / The Education and Science Journal. Vol. 23, № 8. 2021 


\section{Introduction}

Having taken the role of global lingua franca, English has penetrated the world of science and technology, arts and architecture, fashion and designing, business and diplomacy, and education and literacy. Its increasing role in academia has led it to be a "medium of instruction at universities in Europe and worldwide" [1]. In the words of Dearden and Macaro [2], English as a medium of instruction (EMI) refers to "providing instruction in English in contexts where English is not the language commonly spoken". Substantial research-based evidence suggests that there is a rapid increase in EMI [2]. Phuong and Nguyen [3] also affirm the growing popularity of EMI in higher education [HE] globally because of its nature as an international means of communication. Indeed, EMI is spreading far and wide on the globe. Soruç and Griffiths [1] highlight in their study the use of EMI in different parts of the world such as in the Middle East, Austria, Italy, Poland, Spain, the United Arab Emirates (UAE), Korea, Japan and Zimbabwe.

\section{Problem Statement}

Despite decolonisation in Asia in the 1950s, English has remained dominant in education in the post-colonial countries and has been adopted as the MOI for Higher Education [4]. Therefore, although several educational policies have been made over seventy years and a host of changes have been made regarding the medium of instruction in schools, English has consistently been the MOI in higher education of Pakistan [5]. Another reason mentioned by Khan [6] for consistent use of EMI in higher education is the availability of easily available reading material in English.

However, a large number of students in public sector universities come from a non-EMI background as English is the MOI in private schools, while Urdu or vernacular languages, i.e. Sindhi, Pashto are the medium of instruction in the majority of public sector primary, and secondary schools [5]. Moreover, regardless of the nature of the institution, i.e. private or public, vernaculars are the default language(s) for both formal and informal conversation between teacher and students, and students and students.

Besides, Pakistan is a multilingual country with linguistic diversity of 0.802 on the Greenberg index [7]. The calculation is made based on the "population of each language as a proportion of the total population which suggests that a large number of people do not share their first or heritage language" [5]. Therefore, English is sometimes the second or third or fourth language of a large number of students. This is one of the reasons Pakistan has adopted a three-language structure [6] with vernacular fulfilling the first role; Urdu, the second role and English, the third role [8]. 
Given the linguistic diversity of learners and different MOI at the school level, chances of challenges for undergraduates with a non-EMI background in an EMI classroom at university cannot be ruled out. Studies conducted in different non-English countries report the problems undergraduates face in EMI classrooms in speaking, reading, writing and more importantly in comprehension of texts or lectures. Likewise, the students joining the university in $\mathrm{Pa}-$ kistan are said to have several issues in the EMI classroom. Quoting several studies $[6,9,10]$ conducted in the context of Pakistan, Mahboob [5] makes a point that EMI, despite being a medium of instruction in Higher Education of Pakistan since its inception and a most preferred medium of instruction is not devoid of controversy and problems for students. University students who come from non-EMI educational backgrounds experience difficulties in comprehending lectures and making assignments in English.

Although the points raised by the researcher are valid yet it is crucial to note that all three studies that he analysed have been conducted in major cities of Pakistan. And more importantly, the studies [9, 10] have explored the attitudes of learners towards EMI. They do not specifically explore the problems of university students who study in small public sector universities of various cities where educational facilities are fewer and the influence of mother tongue on education is great. Therefore, the existing literature lacks any empirical study focusing on challenges first-year undergraduates with a non-EMI background face in EMI classrooms at a public sector university.

Since students have to study in EMI classrooms for their whole degree programmes, it is imperative to explore the challenges they face in these classes so that effective strategies can be devised to tackle them. So, this study aims to explore challenges first year undergraduates with a non-EMI background face in EMI classroom at a public sector university in Sukkur, Pakistan.

\section{Research Question}

What are the challenges for first-year undergraduates with a non-EMI background in an EMI classroom?

\section{Literature Review}

The perceptions about EMI may vary from context to context. However, research signposts that EMI poses challenges to students in multifaceted ways which may also vary contextually. As Marsh [11] believes that not only developing but also developed countries face challenges related to EMI. This section highlights the challenges of EMI for undergraduates by quoting the quantitative studies followed by qualitative ones conducted in various countries.

Cankaya [12], through an integrative study in a Turkish setting, reports students' difficulty in understanding exam questions. In the case of Taiwan- 
ese students, Yeh [13] mentions with the help of quantitative findings that tertiary level students gain a poor understanding of concepts which affects their disciplinary knowledge. Macaro and Akincioglu [14] also adopted a quantitative design and found that Turkish university students faced issues related to all four skills- reading comprehension, writing, listening comprehension and speaking. Even Belhiah and Elhami [15] adopted a questionnaire and remarked that participants from six universities of the United Arab Emirates (UAE) struggled to comprehend subject content in EMI classes. Similarly, Dafouz and Camacho-Miñano [16] examined the impact of EMI on the academic performance of first-year undergraduates in their Financial Accounting I course in Spanish background. The statistical data revealed that non-EMI students (students taught through Spanish) faced vocabulary-related problems during the course but they participated in class activities very actively. Al Zumor [17], on the other hand, surveyed 264 students of different scientific disciplines in Saudi Arabian context and found that they faced problems of comprehension and assessment with more than $70 \%$ of participants attributing their failure to assessment in English. Meneghetti [18] reports in her master thesis research conducted in Italy that second-year students of different departments faced issues related to teachers' English proficiency that affected their comprehension of the subject.

An important qualitative study on the subject was that of Evans and Morrison [19] who conducted a longitudinal study in Hong Kong and noted that university students faced problems of technical vocabulary, lecture comprehension and academic style. Likewise, Yildiz, Soruc [20] employed an open-ended questionnaire and discovered that students faced issues related to code-switching, teachers' language and technical vocabulary. Adding to the qualitative studies, Soruç and Griffiths [1] conducted a study in the Turkish context to investigate the difficulties English medium instruction posed to the students in International Relations $(n=24)$ and Psychology $(n=15)$ classes. The data collected through video recording of classes, open-ended questionnaires and stimulated recall interviews revealed that the students faced difficulties regarding speaking and listening, teacher and vocabulary.

An interesting thing about the quoted studies is that most of them have adopted a quantitative design and have either endorsed the previous results or have added an increase to the percentage of results already produced findings. Qualitative studies, though very few, have brought to light issues concerning code-switching and academic style. This reflects the importance of the qualitative data to explore the challenges of EMI. 


\section{Methodology}

\section{Context}

The context of this study is a public sector university situated in Sukkur, Pakistan. The university has five departments namely Business Administration, Electrical Engineering, Math, Computer Science and Education. The reason for choosing this context for the study is twofold. First, the university has an innovative programme known as National Talent Hunt Programme through which around 300 students are selected and awarded scholarships on merit-cum-need basis to educate potential but poor students who cannot afford higher education. Since the programme covers various cities of Pakistan and an equal proportion of students are selected from each province, the population is very diverse in terms of socio-economic levels, gender, religion, and educational and cultural background. Second, the ease of access to data for the researcher makes this context a preferable choice.

\section{Design}

This study follows a qualitative case study because it aims to get an indepth understanding of the challenges first-year undergraduates with a nonEMI background face in an EMI classroom. A case study focuses on numerous "instances of a particular phenomenon to provide an in-depth account of events, relationships, experiences, or processes occurring in that particular instance" [21].

\section{Participants}

The major population of the study is first-year undergraduates with a non-EMI background. To get the desired sample of six participants for a semistructured interview, purposive sampling was done. Participants were majorly selected on the basis that they had done their Matriculation and Intermediate (college studies) from a government institution where MOI is either Urdu or any regional language. Besides, participants were selected coming from different areas of the country so that the sample should be varied and different ideas could be got from them. Two of the four research participants were female whereas four were males. Purposive sampling makes it easy for the researcher to select participants with features required for the study [22]. Table 1 shows the pseudonyms of participants, their cities, their degree programme and the semester. 
Description of the participants of the study

\begin{tabular}{|c|c|c|c|}
\hline $\begin{array}{l}\text { Pseudonyms of } \\
\text { Particinants }\end{array}$ & Native Cities & Department & Semester \\
\hline Usama (M) & Sui, Balochistan & $\begin{array}{l}\text { Electrical } \\
\text { Engineering }\end{array}$ & 02 \\
\hline & Kohat, KPK & Maths & 01 \\
\hline $\begin{array}{l}\text { Jawad (M) } \\
\text { Mubashir (M) }\end{array}$ & Layyah, Punjab & Business & 02 \\
\hline $\begin{array}{l}\text { Abdullah (M) } \\
\text { Iqra (F) }\end{array}$ & Gilgit Baltistan & Business & 02 \\
\hline Aqsa $(F)$ & $\begin{array}{l}\text { Sukkur, Sindh } \\
\text { Shikarpur, Sindh }\end{array}$ & $\begin{array}{l}\text { Education } \\
\text { Computer Science }\end{array}$ & $\begin{array}{l}01 \\
01\end{array}$ \\
\hline
\end{tabular}

\section{Data Collection Tools}

\section{Semi-structured interviews}

Semi-structured interviews were conducted with all six participants one by one on a different day so that the data could be handled properly and meanings could be made out of the conducted interviews for further guidance in other interviews. The participants were given free choice to speak either English, Urdu or Sindhi. One of the participants agreed to the interview in English, one in Sindhi and the rest in Urdu. Their interviews were audio-recorded, translated and transcribed. The interview guide comprised three sections: basic introductory information, questions on production (writing and speaking) and comprehension (reading and listening). Semi-structured interviews were conducted because semi-structured interviews provide researchers with some flexibility to shuffle their questions and explore predetermined areas more and more with the help of open-ended questions [23].

\section{Data Analysis}

Data collected through these interviews were analysed using thematic analysis. For the qualitative data analysis and interpretation purpose, a sixstep process - coding, grouping the themes, displaying data, interpreting the findings, and validating the results - defined by Creswell [24] was followed.

\section{Results}

\section{Difficulties in Production (Speaking and Writing)}

The participants of the study were asked about the kind of writing and speaking they did during their degree courses. The participants unanimously responded that they had to prepare notes, write paragraphs, essays and report assignments and they had to write descriptive answers in exams. As for speaking, 
they said they were engaged in group discussions, individual as well as group presentations and they had to have brief discussions with the teachers inside and outside the classrooms.

\section{Ineffective presentation or explanation}

The findings reveal that they face issues in answering the questions of teachers in English especially when they have to speak before other students. Besides, they experience problems in giving their thoughts a clear shape of sentences while speaking to classmates during an activity or responding to the teachers' questions. One participant namely Aqsa said, "I know that what I have in my mind is correct [...] yet whenever I try to say it. I do not mean exactly what I have in my mind". She reported that the same/similar thing happens to her sometimes during a group discussion with classmates also. Upon further inquiry, she said, "I feel this problem because maybe my English is not good".

\section{Organisation and production of coherent answers}

On the other hand, the participant Mubashir said that he faced the issue of organising his thoughts in English and putting them on paper in a coherent way. He said, "My English teacher deducted my 2 marks in the mid-term exam and when I enquired him about the deduction, he showed me the rubrics where 2 marks were allocated for coherence in answers. The teacher said you have many ideas but they have no proper connection and have no flow".

\section{Grammatical structures}

In addition to ineffective explanations and incoherent answers, almost all the participants mentioned at various places in their interviews that grammatical structures created a challenge for them in writing and speaking in English during the class or elsewhere. Upon further inquiry of what sort of grammatical structures bothered them, three of the six participants named the use of tenses in a given situation as challenging for them. For instance, participant Iqra said, "Although I have studied tenses from early years in school, I still feel some difficulty in using proper tense [...] when I present before class, I use present instead of past and my message does not get across". In a slightly better position, participant Abdullah, whose English-speaking skill was comparatively better than the other participants, said, "It was not grammar but punctuation marks and spellings that confuse me in different written quizzes and assignments".

\section{Lack of vocabulary}

Lack of vocabulary was a common issue discussed by all research participants. They believed that lack of vocabulary hinders their expression not just in speaking tasks or activities but also in writing during exams 
especially. This issue was majorly highlighted by two participants: Usama from Sui, Balochistan and Aqsa from Shikarpur, Sindh. One of the reasons for this coincidence might be a poor standard of education in those areas. For example, the female participant said, "My presentation is not good most of the time because I remember all my ideas by heart [...] I have less stock of vocabulary because of which even in exams I cannot recall a proper word to be used to answer the question [...] the words that I use sometimes I do not feel convey the sense I desired to produce". Similarly, the male participant said he crammed his presentation often so that he did not stop in between presentations just because of searching words in mind. He said, "If a presentation is long, I speak slowly because I have to kill time of presentation [...] speaking fast in a long presentation empties my mind and I look for words to utter the succeeding thoughts but I cannot find words. So, I speak slowly".

\section{Difficulties in Comprehension (Reading and Listening)}

As mentioned previously, the participants of the study were asked about the kind of listening and reading they do during their degree courses. They said that they had to study the prescribed course book most of the time for their degree courses. However, they had to go through the hand-outs, slides or any other supporting reading material teachers provided. Similarly, they had a lot of exposure of to listen to English due to peer talk, teacher talk, presentations, course-related audios or videos etc.

\section{Level of language}

Another significant aspect that at least three participants surfaced during their interviews was the level of language related to books and teachers. Participant Jawad said that he understood the content of books most of the time but "some books confuse the sense because of tough language (words) used in the book". Although the participant's view holds water yet nature of the subject and language proficiency of the participant can be important variables in this example. On the other hand, participant Iqra said, "I think my listening skill is good but one of my teachers has done his PhD. from the UK speaks so fast that I barely understand the concept." At another point during the interview, she said, "Sometimes he uses words which I cannot understand". On the contrary, Participant Mubashir said that teachers' accent has not been so much of an issue because of almost similar [South Asian] accent". Another participant, Jawad mentioned that he experienced issues in comprehending Calculus questions. Abdullah said, "Sometimes the instructions given for assignments by teachers are written in such a way that they are not clear to us and we have to ask teachers what to do". 


\section{Partial comprehension}

Interviews of three participants revealed that they faced the issue of partial comprehension mainly due to concentration on language and content simultaneously. Usama said, "I have faced issues in English as I come from a place where there was no environment of English. However, after hard work, I have improved a lot. But when I study any new topic and the teacher explains in English, I feel problems [...] previous knowledge helps understand topics [...] new topic in English doesn't get through easily because I have to focus on understanding language and concept simultaneously".

\section{Psychological pressure}

One of the key findings of the study is the psychological pressure participants said they experience in classes. Appearance on the stage or dais, lack of confidence while speaking before class or directly with the teacher, fear of laughter by classmates if any grammatical mistake is made and shyness, are some of the psychological issues faced by them. Iqra, for example, said, "I speak to friends in group discussions easily after all they are friends and they encourage me if I make mistakes. But when I am asked to present before class, I shudder with the thought of being the centre of everyone's sight".

\section{Discussion}

This study aimed at investigating challenges first-year undergraduates with non-EMI face in an EMI classroom. After analysing the data got from interviews of participants, the study found that first-year undergraduates experience issues such as ineffective presentation, incoherent answers in writing, grammatical structures, lack of vocabulary, and partial comprehension of content and more importantly psychological pressure.

The study findings revealed that participants were unable to deliver effective presentations or give proper answers. They were sure of the accuracy or correctness of their answers yet they felt short of uttering them. This refers to the problem of diffidence in talking English. Apart from this issue of lack of self-confidence, certain cultural factors might be at play because the participant Aqsa appeared to be more religious and reserved out of all participants. So, for a student like her, it might be more challenging to speak in English and become a centre of attention of all classmates. And when one becomes the centre of attention during his/her talk, psychological factors such as fear of being wrong or fear of being laughed at by classmates influence the use of language. This point corroborates with the study of Lee and Sung [25] conducted in the Korean context where they mention the use of EMI as a factor for learners' willingness to communicate. Besides, low proficiency of students in English can also cause 
issues of improper presentation and incoherence as was also pointed out by Kırkgöz [26] in his study in the Turkish context.

Another important aspect of the findings was issues related to language. For example, participants mentioned improper use of tenses and lack of vocabulary as their key issues in production skills and language fluency and speed of their teachers as few issues in EMI classes. Their consistent learning of English at schools and colleges, and their habit of cramming presentations even at the university level portrays a dismal picture of language teaching at lower levels in the Pakistani context. However, the teachers' responsibility to adjust the level of language he uses in the class and the speed at which he speaks are points of consideration for all teachers teaching in EMI classes. This issue was also highlighted by Yildiz, Soruc [20] in their study on challenges to students in EMI courses. These language-related issues result in partial comprehension of content for which students mentioned the use of alternative resources such as lectures in Urdu on YouTube.

\section{Conclusion}

The concept of EMI has spread to many non-English countries and has resulted in courses and degree programmes based on EMI. A qualitative investigation regarding the challenges of undergraduates with a non-EMI background in an EMI classroom in the Pakistani context reveal challenges related to productive skills, language skills, comprehension and psychology. Although they might be able to cope with the challenges themselves by using different means, there is a need to find out workable strategies students might use to deal with these challenges if institutions want to continue EMI policies for their various courses and degree programmes.

\section{Limitations of the study}

Since this is a case study, this study aimed to get an in-depth insight into the challenges of undergraduates with a non-EMI background in an EMI classroom. Although the insights from the participants have been very interesting, the use of one research tool stands as its limitations. Moreover, due to cultural constraints and time limitations, the study could not approach more female participants or an equal number of participants from each department.

\section{References}

1 Soruç A. Griffiths C. English as a medium of instruction: Students' strategies. ELT Journal. 2017; 72 (1): 38-48.

2. Dearden J., Macaro E. Higher education teachers' attitudes towards English medium instruction: A three-country comparison. Studies in Second Language Learning and Teaching. 2016; 6 (3): 455-486. 
3. Phuong Y. H., Nguyen T. T. Students' perceptions towards the benefits and drawbacks of EMI classes. English Language Teaching. 2019; 12 (5): 88-100.

4. Rassool N., Heugh K., Mansoor S. Global issues in language, education and development: Perspectives from postcolonial countries. Clevedon: Multilingual matters; 2007. 304 p.

5. Mahboob A. English medium instruction in higher education in Pakistan: Policies, perceptions, problems, and possibilities. In: Fenton-Smith B., Humphreys P., Walkinshaw I. (eds.). English Medium Instruction in Higher Education in Asia-Pacific. Cham: Springer; 2017. p. 71-91.

6. Khan H. I. An investigation of two universities' postgraduate students and their teachers' perceptions of policy and practice of English medium of instruction (EMI) in Pakistani universities. University of Glasgow; 2013. 313 p.

7. Lewis M. P., Simons G. F., Fennig C. D. Ethnologue: Languages of Asia. SIL International; 2014. 603 p.

8. Mansoor S. Punjabi, Urdu, English in Pakistan: A Sociolinguistic study. Lahore: Vanguard; 1993. $240 \mathrm{p}$.

9. Mahboob A. No English, no future! Language policy in Pakistan. In: Obeng S., Hartford B. (eds.). Political independence with linguistic servitude: The politics about languages in the developing world. UK: Nova Science Pub Inc; 2002. p. 15-39.

10. Mansoor S. Language planning in higher education: A case study of Pakistan. Karachi, Pakistan: Oxford University Press; 2005. 474 p.

11. Marsh D. English as medium of instruction in the new global linguistic order: Global characteristics, local consequences. In: Proceedings of the Second Annual Conference for Middle East Teachers of Science, Mathematics and Computing Abu Dhabi: METSMaC; 2006; Citeseer. p. 30-31.

12. Cankaya P. Challenges in English medium of instruction from the teachers and students' eyes. Online Submission. 2017; 5 (4): 830-839.

13. Yeh C.-C. Taiwanese students' experiences and attitudes towards English-medium courses in tertiary education. RELC Journal. 2014; 45 (3): 305-319.

14. Macaro E., Akincioglu M. Turkish university students' perceptions about English medium instruction: Exploring year group, gender and university type as variables. Journal of Multilingual and Multicultural Development. 2018; 39 (3): 256-270.

15. Belhiah H., Elhami M. English as a medium of instruction in the Gulf: When students and teachers speak. Language Policy. 2015; 14 (1): 3-23.

16. Dafouz E., Camacho-Miñano M. M. Exploring the impact of English-medium instruction on university student academic achievement: The case of accounting. English for Specific Purposes. 2016; 44: 57-67.

17. Al Zumor A. Q. Challenges of using EMI in Teaching and learning of university scientific disciplines: Student voice. International Journal of Language Education. 2019; 1 (1): 74-90.

18. Meneghetti M. English as a medium of instruction at the University of Padova: Interaction in the classroom [master's thesis on the Internet]. Università degli Studi di Padova; 2016 [cited 2020 Feb 01]. 142 p. Available from: http://tesi.cab.unipd.it/53362/1/ MICHELA_MENEGHETTI_2016.pdf

19. Evans S., Morrison B. Meeting the challenges of English-medium higher education: The first-year experience in Hong Kong. English for Specific Purposes. 2011; 30 (3): 198-208. 
20. Yildiz M., Soruc A., Griffiths C. Challenges and needs of students in the EMI (English as a medium of instruction) classroom. Konin Language Studies. 2017; 5 (4): 387-402.

21. Denscombe M. The good research guide: For small-scale social research projects. UK: McGraw-Hill Education; 2014. 376 p.

22. Etikan I., Musa S. A., Alkassim R. S. Comparison of convenience sampling and purposive sampling. American Journal of Theoretical and Applied Statistics. 2016; 5 (1): $1-4$.

23. Kallio H., Pietilä A. M., Johnson M., Kangasniemi M. Systematic methodological review: Developing a framework for a qualitative semi-structured interview guide. Journal of Advanced Nursing. 2016; 72 (12): 2954-2965.

24. Creswell J. W. Educational research: Planning, conducting, and evaluating quantitative. NJ: Prentice Hall Upper Saddle River; 2002. 673 p.

25. Lee H., Sung K. WTC in EMI: Correlational factors and college learners' perceptions. 외국어교육. 2014; 21 (2): 75-106.

26. Kırkgöz Y. Students' and lecturers' perceptions of the effectiveness of foreign language instruction in an English-medium university in Turkey. Teaching in Higher Education. 2009; 14 (1): 81-93.

\section{Information about the author:}

Kamran Akhtar Siddiqui - Lecturer in English, Faculty of Math and Social Sciences, Sukkur IBA University; ORCID 0000-0002-7507-6072; Sukkur, Pakistan. E-mail: Kamran. akhtar@iba-suk.edu.pk

Conflict of interest statement. The author declares that there is no conflict of interest.

Received 27.04.2021; accepted for publication 08.09.2021.

The author has read and approved the final manuscript.

\section{Ннформация об авторе:}

Сиддики Камран Ахтар - преподаватель английского языка факультета математических и социальных наук Университета Суккур IBA; ORCID 0000-0002-75076072; Суккур, Пакистан. E-mail: Kamran.akhtar@iba-suk.edu.pk

информация о конфликте интересов. Автор заявцяет об отсутствии конфцикта интересов.

Статья поступила в редакцию 27.04.2021; принята в печать 08.09.2021.

Автор прочитал и одобрил окончательный вариант рукописи. 